\title{
PELATIHAN KEPEMIMPINAN KENABIAN UNTUK MENINGKATKAN KOMITMEN MENGAJAR GURU
}

\section{PROPHETIC LEADERSHIP TRAINING TO INCREASE THE TEACHER'S TEACHING COMMITMENT}

\author{
Ela Minchah Laila Alawiyah \\ Fakultas Keguruan dan Ilmu Pendidikan, Universitas Muhammadiyah Magelang, Magelang \\ Email: emlaa@ymail.com \\ Sukarti \\ Ratna Syifa'a Rachmahana \\ Fakultas Psikologi dan IImu Sosial Budaya Universitas Islam Indonesia, Yogyakarta
}

\begin{abstract}
This study aims to determine whether prophetic leadership training can increase the teacher's teaching commitment, 22 subjects in this study were all of the teachers at Islamic Elementary School " $H$ " Yogyakarta. The design of study using The One Group Pretest-Posttest Design. The data are analyzed quantitavely using wilcoxon signed ranks test. The results show that prophetic leadership training can increase the teacher's teaching commitment at islamic integrated elementary school " $\mathrm{H}$ ", demonstrated by the comparison of the teaching commitment before the training (pretest) and after the training (posttest) showing the value of 0,000 Sig (Sig value $<0,05$ ). The result shows that the hypothesis that there are differences in teacher's teaching commmitment before and after training is acceptable. The teacher's teaching commitment a month after training (follow up) values 0,006 (Sig value $<0,05$ ), meaning that the hypothesis of teacher's teaching commitment difference before the training (pretest) and a month after training (follow up) is acceptable. Furthermore, the teacher's teaching commitment after training (posttest) and a month after training (follow up) showing the value of 0,426 Sig (Sig value $>0,05$ ). The result shows the hypothesis that there are differences in teacher's teaching commitment after (posttest) and a month after training (follow up) is unacceptable. So the conclusion of this study is prophetic leadership training can increase the teacher's teaching commitment.
\end{abstract}

Key words: Teacher's Teaching Commitment, Prophetic Leadership.

\begin{abstract}
ABSTRAK
Penelitian ini bertujuan untuk menguji apakah Pelatihan Kepemimpinan Kenabian dapat meningkatkan komitmen mengajar guru, 22 subjek dalam penelitian ini adalah guru-guru di SDIT " $\mathrm{H}$ " Yogyakarta. Desain penelitian yang digunakan adalah The one Group Pretest-postest Design. Analisis data yang digunakan adalah analisis kuantitatif dengan menggunakan wilcoxon signed ranks test. Hasil penelitian yaitu pelatihan kepemimpinan kenabian dapat meningkatkan komitmen mengajar guru SDIT " $\mathrm{H}$ ", ditunjukkan dari perbandingan komitmen mengajar guru sebelum pelatihan (pretest) dan setelah setelah pelatihan (pascates) diketahui nilai Sig 0,000 (nilai sig < 0,05). Hal ini berarti hipotesis diterima yaitu ada perbedaan komitmen mengajar guru yang signifikan antara sebelum pelatihan (pretest) dan setelah pelatihan (pascates), kemudian komitmen mengajar guru dilihat lagi hasilnya satu bulan setelah pelatihan (follow up) diketahui nilai Sig 0,006 (nilai Sig < 0,05). Hal ini berarti hipotesis diterima yaitu ada perbedaan komitmen mengajar guru yang signifikan antara sebelum pelatihan (pretest) dan satu bulan setelah pelatihan (follow up). Komitmen mengajar guru setelah pelatihan kepemimpinan kenabian (pascates) dan satu bulan setelah pelatihan (follow
\end{abstract}

18 | Jurnal Intervensi Psikologi, Vol 6 Juni 2014 | 
up) diketahui nilai Sig 0,426 (nilai Sig $>0,05$ ). Hal ini berarti hipotesis ditolak yaitu tidak ada perbedaan komitmen mengajar guru yang signifikan setelah pelatihan (pascates) dengan satu bulan setelah pelatihan (follow up). Kesimpulan dari penelitian ini adalah pelatihan kepemimpinan kenabian dapat meningkatkan komitmen mengajar guru SDIT “ $\mathrm{H}$ "

Kata kunci: Komitmen Mengajar Guru, Kepemimpinan Kenabian.

Perkembangan sebuah bangsa tidak lepas dari peran pendidikan sebagai upaya untuk mampu bertahan dalam kompetisi global. Pendidikan pun tidaklah lepas dari proses belajar mengajar. Proses belajar mengajar yang berkualitas dapat diselenggarakan di kelas dengan benarbenar efektif dan berguna untuk mencapai kemampuan pengetahuan, sikap, dan ketrampilan yang diharapkan jika guru sebagai pendidik memiliki komitmen yang tinggi untuk mewujudkannya (Park \& Henkin, 2005).

Guru merupakan salah satu aset penting dalam proses belajar mengajar, karena guru merupakan orang yang bertanggung jawab untuk membantu para peserta didik secara optimal dalam pendidikan serta membimbing mereka untuk mencapai kedewasaan masingmasing. Guru merupakan orang yang memainkan peran penting dalam perkembangan peserta didik. Oleh karena itu penting bagi guru untuk memiliki komitmen dalam melaksanakan tugas-tugasnya dengan sebaik mungkin (Erawan, 2010).

Undang-undang Republik Indonesia No. 14 Tahun 2005 menyebutkan bahwa guru adalah pendidik profesional dengan tugas utama mendidik, mengajar, membimbing, mengarahkan, melatih, menilai, dan mengevaluasi peserta didik pada pendidikan anak usia dini, pendidikan dasar, dan pendidikan menengah. Berdasarkan Undang-undang tersebut, maka keberadaan guru perlu mendapatkan perhatian serius dengan rumusan aturan yang jelas agar kualitas pendidikan di Indonesia menjadi lebih baik.

Adz-Dzakiey (2009) mengemukakan bahwa guru juga merupakan pemimpin. Dalam perspektif Pendidikan Islam, guru memiliki beberapa sebutan dengan peran-perannya yang khas, antara lain: 1) ustadz, yakni guru dituntut untuk komitmen terhadap profesionalisme dalam mengemban tugasnya. 2) muallim, yakni guru dituntut untuk mampu menjelaskan hakekat ilmu pengetahuan yang diajarkannya, serta menjelaskan dimensi teoritis dan praktisnya, dan berusaha membangkitkan peserta didik untuk mengamalkannya. 3) murabby, yakni mendidik dan menyiapkan peserta didik agar mampu berkreasi, sekaligus mengatur dan memelihara hasil kreasinya untuk tidak menimbulkan malapetaka bagi dirinya, masyarakat dan alam sekitarnya. 4) mursyid, yakni berusaha menularkan penghayatan akhlak dan kepribadian kepada peserta didik, baik berupa etos ibadah, kerja, belajar, maupun dedikasinya lillahi ta'ala. 5) mudarris, yakni guru bertugas mencerdaskan peserta didiknya. 
6) muaddib, yakni guru adalah orang yang beradab sekaligus memiliki peran dan fungsi untuk membangun peradaban yang berkualitas di masa depan.

Tugas utama guru adalah mendidik, mengajar, membimbing, meng-arahkan, melatih, menilai, dan meng-evaluasi peserta didik. Dalam penelitian ini peneliti membatasi masalah penelitian ini mengenai komitmen guru dalam melakukan tugasnya sebagai pendidik, yakni mengajar. Istilah komitmen meng-ajar guru dapat disebut dengan "teaching commitment" (Colladarci dalam Erawan, 2010).

Ching dan Kee (2012) mengungkapkan bahwa komitmen mengajar guru adalah salah satu kunci ikatan psikologis antara guru dengan pekerjaannya sebagai pengajar. Komitmen mengajar guru memengaruhi kualitas, nilai, sikap dan keterampilan yang dimiliki guru. Crosswell dan Elliott (2012) menambahkan bahwa komitmen mengajar guru diidentifikasikan sebagai salah satu faktor kunci keberhasilan pendidikan, komitmen mengajar guru merupakan hubungan antara guru dengan performansi kerja guru serta kemampuannya untuk berinovasi dan mengembangkankan ide-ide baru sehingga dapat berpengaruh pada prestasi peserta didik.

Colladarci (Erawan, 2010) mengungkapkan bahwa komitmen mengajar guru merupakan indikator dari kelekatan guru secara psikologis dengan pekerjaannya sebagai guru. Komitmen mengajar memengaruhi intensitas dan stabilitas guru dalam menampilkan kemampuannya sebagai pengajar. Jika seorang guru memiliki komitmen mengajar yang tinggi maka kemungkinan besar hasil yang dicapai guru lebih mampu mengatasi permasalahan yang timbul di sekolah.

Erawan (2010) mengungkapkan bahwa aspek-aspek komitmen mengajar guru antara lain: (a) Aspek affective, yakni guru mau menerima nilai-nilai dan tujuan mengajar, (b) Aspek normative, yakni guru merujuk pada apa yang dirasakannya terkait dengan tanggung jawab dan kewajibannya sebagai pendidik, dan (c) Aspek continuance, yakni guru mau bertahan dalam pekerjaannya terutama dalam mengajar terkait dengan manfaat \& peluang yang didapatkan guru dari mengajar.

Guru yang memiliki komitmen mengajar rendah cenderung kurang peduli dengan ketrampilan yang dimilikinya, kurang memiliki disiplin dan tanggung jawab akan pekerjaannya, sedangkan guru yang memiliki komitmen mengajar tinggi akan berusaha lebih baik dalam mengajar dan berusaha semaksimal mungkin demi kepentingan pendidikan. Kualitas guru dapat memberikan kontribusi bagi sekolah demi keberhasilan pendidikan (Erawan, 2010).

Guru sebagai pemimpin hendaknya mampu menjadi teladan bagi peserta didiknya. Namun, data hasil observasi dan wawancara peneliti selama Praktik Kerja Profesi Psikolog di SDIT " $\mathrm{H}^{\text {" pada }}$ tanggal 20 Oktober 2011 hingga 20 Januari 2012 menunjukkan bahwa guru- 
guru cenderung kurang optimal dalam bekerja terutama saat mengajar, beberapa guru terlambat datang ke sekolah dan terlambat memulai jam pelajaran. Guru kurang tegas saat mengajar, beberapa guru kurang memiliki rasa tanggung jawab dan disiplin terhadap kewajiban sebagai guru. Beberapa guru merasa belum pantas disebut sebagai guru profesional karena cenderung kurang dapat aktif ketika mengajar di dalam kelas. Saat kelas tampak kurang kondusif, guru tetap memberikan penjelasan mengenai materi pelajaran tanpa memberikan peringatan, sehingga para peserta didik bebas bermain atau keluar-masuk kelas (Alawiyah, 2012).

Akibat dari kecenderungan kurang optimal saat mengajar, terlambat memulai jam pelajaran, kurang tegas saat mengajar, kurang memiliki rasa tanggung jawab dan disiplin terhadap kewajiban sebagai guru, para peserta didik bebas bermain atau keluar-masuk kelas. Penelitian ini dimaksudkan untuk memberikan intervensi berupa Pelatihan Kepemimpinan Kenabian kepada guru-guru di SDIT " $\mathrm{H}$ " sebagai upaya untuk menguji apakah Pelatihan Kepemimpinan Kenabian dapat meningkatkan komitmen mengajar guru di SDIT " $\mathrm{H}$ ".

Kepemimpinan kenabian adalah kemampuan mengendalikan diri dan memengaruhi orang lain dengan tulus untuk mencapai tujuan bersama sebagaimana dilakukan oleh para Nabi. Kemampuan mengendalikan diri sebagaimana dilaksanakan oleh para Nabi mempunyai arti bahwa kemampuan tersebut diperjuangkan melalui kekuatan pencerahan jiwa dan pembersihan ruhani. Sebelum memengaruhi orang lain, pemimpin dalam kepemimpinan kenabian telah mampu memengaruhi dan mengatur dirinya. Kekuatan pencerahan jiwa mengandung arti orang yang mempengaruhi berarti sudah atau sedang mempraktikkan apa yang dipengaruhkan sebagai wujud dari jiwanya yang telah tercerahkan (Budiharto \& Himam, 2006), dengan kata lain proses memengaruhi dijalankan dengan keteladanan.

Pelatihan Kepemimpinan Kenabi-an yang akan dilaksanakan di SDIT " $\mathrm{H}$ " merupakan sebuah kegiatan belajar terencana yang mengacu pada aspekaspek kepemimpinan kenabian (Budiharto \& Himam (2006), yaitu: (a) Sidiq yang berarti benar, lurus, dan jujur. Jujur meliputi jujur kepada Tuhan, diri sendiri/ nurani, orang lain, dan jujur terhadap tugas dan tanggung jawab. Sabar dan konsisten termasuk sidiq. (b) Amanah memiliki makna profesional, bisa dipercaya, loyal/ committed terhadap nurani, terhadap Tuhan, terhadap pemimpin, pengikut, dan rekan kerjanya, selama pimpinan, pengikut, dan rekan kerja loyal kepada Tuhannya. (c) Tabligh, berasal dari kata balagha yang berarti sampai, maksudnya menyampaikan informasi seperti adanya. Tabligh dalam kepemimpinan juga bermakna open management, serta beramar ma'ruf nahi munkar (mengajak melakukan kebaikan dan menjauhi kejahatan). Perilaku pemimpin 
tabligh antara lain adalah berani menyatakan kebenaran dan bersedia mengakui kekeliruan. Apa yang benar dikatakan benar, apa yang salah dikemukakan salah. Jika tidak tahu menyetakan tidak tahu. (d) Fathonah berarti cerdas yang dibangun dari ketakwaan kepada Tuhan, dan memiliki ketrampilan yang teruji. Perilaku pemimpin yang fathonah terekspresi pada etos kerja dan kinerja pemimpin yang memiliki skill yang teruji dan terampil, serta mampu untuk memecahkan masalah secara cepat dan tepat.

Diharapkan pelatihan ini mampu untuk mengembangkan pengetahuan, kecakapan dan kemampuan mengenai keteladanan dari kepemimpinan kenabian secara umumnya dan secara khusus mampu untuk meningkatkan komitmen mengajar guru di SDIT " $\mathrm{H}$ ".

Peneliti memilih Pelatihan Kepemimpinan Kenabian sebagai inter-vensi untuk meningkatkan komitmen mengajar guru karena di dalam aspek Pelatihan Kepemimpinan Kenabian terda-pat aspek amanah yang erat kaitannya dengan masalah komitmen. Kata kunci amanah memiliki relevansi dengan istilah berkomitmen tinggi (highly commited). Target yang ingin dicapai dalam sesi amanah adalah para peserta pelatihan memiliki kesadaran atas tanggung jawabnya sebagai guru, sehingga peserta mampu meningkatkan komitmen mengajar guru di SDIT " $\mathrm{H}$ ", di samping itu guru sebagai pemimpin perlu memiliki wawasan mengenai karakteristik ideal yakni Rosulullah SAW dan menerapkannya dalam kehidupan.

Pelatihan Kepemimpinan Kenabian dirancang berdasarkan teori experiential learning yang menyatakan bahwa pelatihan mampu mengubah struktur kognitif, sikap serta ketrampilan yang dimiliki oleh peserta. Melalui pelatihan pertama-tama peserta diarahkan untuk menyadari suatu ketrampilan dikuasai dan menyadari komponen-komponen atau langkah-langkah yang perlu dilakukan supaya suatu ketrampilan dapat dikuasai dengan baik (Andansari, 2010).

Pelatihan Kepemimpinan Kenabian melibatkan aktivitas yang nyata setelah mendapatkan materi dan ketrampilan yang diperoleh. Salah satu kelebihan dalam pelatihan adalah dalam pelatihan individu tidak belajar seorang diri, akan tetapi belajar dalam suatu kelompok, karena pelatihan diikuti oleh lebih dari satu peserta. Menurut experiential learning, individu akan dapat menerima materi dan ketrampilan dengan lebih baik jika berada dalam suatu kelompok dibandingkan dengan saat menerima materi seorang diri Johnson \& Johnson, 2001).

Metode pelaksanaan pelatihan yang digunakan peneliti mencakup diskusi, keteladanan, umpan balik dan gladian. Metode instruksi melatih kemampuan verbal peserta, dan diskusi meningkatkan kesadaran peserta terhadap ketrampilan yang dilatihkan, dalam hal ini adalah kemampuan untuk meningkatkan komitmen mengajar guru. Keteladanan 
berkaitan dengan demonstrasi ketrampilan khusus atau perilaku orang lain dalam kelompok, kemudian diamati oleh peserta pelatihan. Teknik ini digunakan untuk mendorong peserta pelatihan meniru melakukan perilaku yang diharapkan.

Pelatihan Kepemimpinan Kenabian secara tipikal meningkatkan latihan terhadap ketrampilan yang ditargetkan. Pengulangan perilaku atau bermain peran, dapat dilakukan dengan latihan sederhana dari perilaku yang ditargetkan atau mungkin dikombinasikan dengan bermain peran. Hal yang penting adalah umpan balik, yakni berasal dari komentar yang diberikan trainer maupun teman kelompok mengenai perilaku yang ditampilkan dengan benar dan perilaku yang sebaiknya diubah, sehingga peserta pelatihan dapat belajar dari keberhasilan dan kesalahannya. Peserta juga diminta untuk mengemukakan masalah-masalah yang dihadapinya, khususnya dalam situasi mengajar. Teknik ini bertujuan untuk mendorong peserta mengekspresikan diri dan mengembangkan perilaku asertifnya. Pada pelaksanaannya, pelatihan ini menggunakan modul sebagai sarana penyampaian pelatihan. Modul ini disusun dari aspek-aspek kepemimpinan kenabian yaitu sidiq, amanah, tabligh, fathonah disertai dengan adanya modifikasi beberapa materi terkait dengan kompetensi guru.

Pelatihan Kepemimpinan Kenabian diharapkan mampu meningkatkan sikap dan ketrampilan yang ditargetkan yakni komitmen mengajar guru. Komitmen mengajar guru akan ditingkatkan melalui pemberian materi pelatihan yang terkandung dalam aspek-aspek kepemimpinan kenabian.

Berdasarkan uraian di atas, maka peneliti berasumsi bahwa Pelatihan Kepemimpinan Kenabian penting untuk dilakukan di SDIT " $\mathrm{H}$ " dalam rangka meningkatkan komitmen mengajar guru. Tujuan dari penelitian ini adalah untuk menguji apakah pelatihan ini dapat memberikan dampak yaitu penanganan atau intervensi pada guru dalam upaya meningkatkan komitmen guru dalam mengajar di SDIT " $\mathrm{H}$ ". Hipotesis dalam penelitian ini adalah:

1. Ada perbedaan komitmen mengajar guru yang signifikan antara sebelum pelatihan dan sesudah pelatihan.

2. Ada perbedaan komitmen mengajar guru yang signifikan antara sebelum pelatihan dan satu bulan setelah pelatihan.

3. Ada perbedaan komitmen mengajar guru yang signifikan antara sesudah pelatihan dan satu bulan setelah pelatihan.

\section{METODE PENELITIAN}

\section{Subjek Penelitian}

Subjek yang diberi pelatihan dalam penelitian ini adalah guru-guru SDIT " $\mathrm{H}$ " Yogyakarta, yakni berjumlah 22 orang. Adapun karakteristiknya adalah (a) Tingkat pendidikan memiliki jenjang dari S1 hingga Strata 2 (S2), (b) Usia berkisar antara 22-45 tahun, (c) Mengajar di SDIT 
" $\mathrm{H}$ ", dan (d) Memiliki skor komitmen mengajar yang rendah/ sedang.

\section{Rancangan Penelitian}

Rancangan penelitian ini adalah quasi eksperimen, dengan rancangan pretest-pascates. Para guru diukur komitmen mengajarnya dengan menggunakan skala komitmen mengajar guru. Seluruh subjek penelitian dimasukkan ke dalam satu kelompok, yaitu kelompok eksperimen tanpa kelompok kontrol (One Group Pretest-Posttest Design). Kelompok eksperimen diberi perlakuan berupa Pelatihan Kepemimpinan Kenabian.

\section{Metode pengumpulan data}

Metode pengumpulan data dalam penelitian ini menggunakan skala komitmen mengajar guru yang mengacu pada aspek-aspek dalam komitmen, yakni Aspek Affective, Aspek Continuance, dan Aspek Normative yang telah disusun oleh Bahry (2012) dan dimodifikasi oleh peneliti. Skala Komitmen Mengajar guru bersifat favourable dan unfavourable. Bentuk skala komitmen mengajar guru ini memiliki 7 tipe pilihan jawaban bergerak dari Sangat Tidak Sesuai (STS) hingga Sangat Sesuai (SS). Alat ukur Komitmen Guru dalam Mengajar digunakan pada saat pretest, pascates dan follow-up agar hasilnya dapat diperbandingkan.

Selain itu untuk melengkapi data peserta, juga digunakan observasi dan wawancara. Lembar observasi dan wawancara dibuat oleh peneliti yang diisi oleh para observer berjumlah 6 orang. Adapun lembar observasi terdiri dari lembar naratif dan check list. Untuk mengevaluasi intervensi, peserta diberikan lembar kerja peserta yang berisi pertanyaan dan kolom jawaban yang memudahkan subjek penelitian dalam menyerap materi pelatihan serta diberi lembar evaluasi peserta. Lembar evaluasi pelatihan terdiri dari lembar evaluasi reaksi peserta ketika mengikuti pelatihan, pengetahuan yang didapat, dan hasil yang didapat dari pelatihan yang diikuti.

\section{Prosedur Penelitian}

Tahap Persiapan Penelitian. Sebelum melaksanakan pelatihan peneliti melakukan beberapa tahap. Pertama, perijinan. Informed consent bagi peserta terdapat penjelasan mengenai tujuan dan proses penelitian yang akan dilaksanakan di SDIT " $H$ ". Subjek penelitian diminta membaca dan menandatangani kesediaannya dalam mengikuti pelatihan.

Kedua, penyusunan modul. Modul yang disusun oleh peneliti adalah hasil pengembangan dari aspek-aspek kepemimpinan kenabian yaitu sidiq, amanah, tabligh, fathonah. Peneliti melakukan uji coba dan beberapa kali perombakan terhadap modul karena disesuaikan dengan kondisi lapangan. Setelah modul disetujui oleh penilai professional dan trainer maka peneliti menggandakan modul tersebut.

Ketiga, persiapan trainer. Trainer yang akan memberikan pelatihan adalah 
seorang tenaga psikolog profesional yang sudah terbiasa memberikan pelatihan kepemimpinan kenabian. Keempat, persiapan tempat pelatihan. Peneliti mempersiapkan tempat pelatihan 2 hari sebelum pelatihan berlangsung dengan dibantu oleh beberapa observer dan staf sekolah.

Kelima, melakukan analisis kebutuhan. Asesmen berupa observasi dan wawancara dalam rangka kroscek data dilakukan kembali oleh peneliti satu bulan sebelum diadakan pelatihan. Keenam, uji coba alat ukur. Uji coba Skala Komitmen Mengajar Guru dilakukan pada tanggal 6-20 Juli 2012 kepada 50 orang, dari 30 aitem yang diujicobakan, terdapat 16 item tidak valid atau gugur, kemudian didapat 14 item valid dengan koefisien validitas berkisar antara 0,374-0,750. Dengan angka koefisien reliabilitas $\alpha$ sebesar 0,884, maka dapat dikatakan bahwa Skala Komitmen Mengajar Guru memiliki reliabilitas yang tinggi.

Keenam, uji kelayakan modul pelatihan. Uji Kelayakan Modul/ Professional Judgement dilakukan oleh dua orang praktisi yang telah memiliki pengalaman dalam Pelatihan Kepemimpinan Kenabian yakni dilaksa-nakan pada tanggal 1 Juni 2012 dan 3 Juli 2012.

Tahap pelaksanaan penelitian, subjek diberi intervensi berupa Pelatihan Kepemimpinan Kenabian. Pelatihan berlangsung selama dua hari, hari pertama berlangsung selama 8 jam dimulai dari pukul 07.00 dan berakhir pukul 15.00 siang. Hari pertama diisi dengan 4 materi yaitu Membangun Komitmen Belajar, Menjadi Guru yang Profesional, Pemimpin Ideal dan Self Awareness, dan Pengembangan Potensi Kepemimpinan Kenabian bagian I (SidiqAmanah), dengan diselingi oleh istirahat. Hari kedua berlangsung selama 5 jam, mulai dari pukul 07.00 pagi dan berakhir pukul 12.00 siang. Materinya adalah pengembangan potensi Kepemimpinan Kenabian bagian II (Tabligh-Fathonah), Action Plan dan Evaluasi. Metode pelatihan yang dipakai peneliti adalah diskusi, ceramah, games, dan penayangan gambar/video. 
Tabel 4. Sesi Pelatihan Kepemimpinan Kenabian

\begin{tabular}{|c|c|}
\hline Sesi & Tujuan \\
\hline $\begin{array}{l}\text { Membangun } \\
\text { Komitmen belajar }\end{array}$ & $\begin{array}{l}\text { - Peserta memiliki harapan dan komitmen selama pelatihan } \\
\text { berlangsung }\end{array}$ \\
\hline $\begin{array}{l}\text { Menjadi Guru yang } \\
\text { Professional }\end{array}$ & $\begin{array}{l}\text { - Peserta memiliki komitmen dan kompetensi dalam } \\
\text { menjalankan tugasnya } \\
\text { - Peserta menyadari kurangnya optimal dalam bekerja } \\
\text { terutama saat mengajar }\end{array}$ \\
\hline $\begin{array}{l}\text { Pemimpin Ideal dan } \\
\text { Self Awareness }\end{array}$ & $\begin{array}{l}\text { - Peserta termotivasi untuk bisa sukses seperti idolanya } \\
\text { - Peserta memahami perannya di dalam kelas sebagai } \\
\text { pemimpin }\end{array}$ \\
\hline $\begin{array}{l}\text { Pengembangan } \\
\text { Potensi Kepemimpin- } \\
\text { an Kenabian } \\
\text { (Sidiq-Amanah) }\end{array}$ & $\begin{array}{l}\text { - Mensyukuri peristiwa yang menyenangkan, dan } \\
\text { memaafkan peristiwa menyedihkan apa adanya } \\
\text { - Peserta memiliki komitmen dan tanggung jawab untuk } \\
\text { melaksanakan kewajibannya sebagai guru }\end{array}$ \\
\hline $\begin{array}{l}\text { Pengembangan } \\
\text { Potensi Kepemimpin- } \\
\text { an Kenabian } \\
\text { (Tabligh-Fathonah) }\end{array}$ & $\begin{array}{l}\text { - Peserta mampu menerapkan komunikasi asertif dalam } \\
\text { komunikasi sehari-hari di sekolah, khususnya di kelas } \\
\text { - Peserta mampu untuk menerapkan tahapan pemecahan } \\
\text { masalah dalam kehidupan dan pekerjaan }\end{array}$ \\
\hline Action Plan & $\begin{array}{l}\text { - Peserta mampu menetapkan visi \& misi hidup yang selaras } \\
\text { dengan keyakinan kepada Allah SWT } \\
\text { - Peserta memiliki komitmen dan perilaku selaras dengan } \\
\text { keyakinan pada Allah SWT } \\
\text { - Peserta mampu menetapkan rencana aksi untuk } \\
\text { mengembangkan potensi dirinya }\end{array}$ \\
\hline
\end{tabular}

\section{ANALISIS DATA}

Teknik analisis yang digunakan dalam penelitian ini adalah wiecoxon signet rank test.

\section{HASIL PENELITIAN}

\section{Deskriptif}

Pretest menginformasikan kemampuan awal subjek sebelum dilakukan penelitian, yakni pada tanggal 11 Agustus
2012. Konstansi adalah skor hasil pascates dikurangi dengan hasil pretest setiap subjek. Pretest dan pascates ini juga berguna untuk mengukur perubahan akibat efek dari perlakuan (Bowling 2002), jadi skor yang diperoleh adalah peningkatan atau penurunan dari komitmen guru dalam mengajar akibat diberi perlakuan. Hasil yang didapat dari pretest, yakni: 
Tabel 2. Deskripsi Data Pretest

\begin{tabular}{ccccccccc}
\hline \multirow{2}{*}{ Variabel } & \multicolumn{4}{c}{ Empirik } & \multicolumn{5}{c}{ Hipotetik } \\
\cline { 2 - 8 } & Min & Max & Rerata & SD & Min & Max & Rerata & SD \\
\hline $\begin{array}{c}\text { Komitmen } \\
\begin{array}{c}\text { Mengajar } \\
\text { Guru }\end{array}\end{array}$ & 48 & 87 & 39 & 6,5 & 14 & 98 & 84 & 14 \\
\hline
\end{tabular}

Tabel 3. Hasil Pretest Subjek Penelitian

\begin{tabular}{cccc}
\hline Rentang Hasil & Kategori & Jumlah Peserta & $\%$ \\
\hline$X<42$ & Rendah & - & 0 \\
$42 \leq X<70$ & Sedang & 8 & $36 \%$ \\
$X>70$ & Tinggi & 14 & $64 \%$ \\
\hline
\end{tabular}

Setelah diberikan pelatihan, maka tahapan selanjutnya adalah pascates atau pascates I yakni tanggal 12 Agustus 2012, dalam tahap ini subjek kembali diberikan skala yang sama dengan yang diberikan saat prates yaitu skala komitmen mengajar guru, yang dimaksudkan untuk mengetahui apakah terjadi peningkatan maupun penurunan setelah subjek diberi perlakuan. Setelah pascates I selesai maka follow-up (pascates II) dilakukan dengan jarak waktu 1 bulan setelah pascates I yakni tanggal 15 September 2012. Hal ini dimaksudkan agar bisa mengetahui perubahan yang terjadi setelah masa pelatihan sampai dengan kembali bekerja (Noe, 1998).

Tabel 5. Deskripsi Data Pascates

\begin{tabular}{ccccccccc}
\hline \multirow{2}{*}{ Variabel } & \multicolumn{4}{c}{ Empirik } & \multicolumn{4}{c}{ Hipotetik } \\
\cline { 2 - 8 } & Min & Max & Rerata & SD & Min & Max & Rerata & SD \\
\hline $\begin{array}{c}\text { Komitmen } \\
\text { Mengajar } \\
\text { Guru }\end{array}$ & 64 & 97 & 33 & 5,5 & 14 & 98 & 84 & 14 \\
\hline
\end{tabular}

Tabel 6. Kategori Hasil Tes Pada Tahap pascates Subjek Penelitian

\begin{tabular}{cccc}
\hline Rentang Hasil & Kategori & Jumlah & \% \\
\hline$X<42$ & Rendah & - & 0 \\
$42 \leq X<70$ & Sedang & 3 & $13 \%$ \\
$X>70$ & Tinggi & 19 & $87 \%$ \\
\hline
\end{tabular}


Tabel 7. Deskripsi Data Follow Up

\begin{tabular}{ccccccccc}
\hline \multirow{2}{*}{ Variabel } & \multicolumn{4}{c}{ Empirik } & \multicolumn{5}{c}{ Hipotetik } \\
\cline { 2 - 8 } & Min & Max & Rerata & SD & Min & Max & Rerata & SD \\
\hline $\begin{array}{c}\text { Komitmen } \\
\begin{array}{c}\text { Mengajar } \\
\text { Guru }\end{array}\end{array}$ & 72 & 94 & 22 & 3,6 & 14 & 98 & 84 & 14 \\
\hline
\end{tabular}

Tabel 8. Kategori Hasil Tes Pada Tahap Follow-up Subjek Penelitian

\begin{tabular}{cccc}
\hline Rentang Hasil & Kategori & Jumlah & $\%$ \\
\hline$X<42$ & Rendah & - & 0 \\
$42 \leq X<70$ & Sedang & - & $0 \%$ \\
$X>70$ & Tinggi & 22 & $100 \%$ \\
\hline
\end{tabular}

\section{Hasil uji hipotesis}

Analisis data yang digunakan untuk pengujian hipotesis penelitian ini adalah dengan Teknik analisis yang digunakan teknik analisis wilcoxon signed ranks test, yaitu membandingkan nilai awal (pretest) dengan nilai akhir (pascates l) dan membandingkan nilai awal (pretest) dengan nilai akhir (pascates II/ follow up). Analisis penelitian ini menggunakan SPSS seri 16.0.

Berdasarkan analisis hasil penelitian yang telah dilakukan secara keseluruhan menggunakan wilcoxon signed ranks test, didapatkan data prates dan pascates skala komitmen mengajar guru diketahui Sig 0,000 (nilai Sig $<0,05$ ) berarti hipotesis diterima sehingga menunjukkan ada perbedaan komitmen mengajar guru yang signifikan sebelum pelatihan (pretest) dan setelah Pelatihan Kepemimpinan Kenabian (pascates).

Komitmen mengajar guru dilihat lagi hasilnya satu bulan setelah pelatihan (follow-up) diketahui nilai Sig 0,006 (nilai Sig $<0,05)$ yang berarti hipotesis diterima yaitu ada perbedaan komitmen mengajar guru yang signifikan antara sebelum pelatihan (pretest) dan satu bulan setelah pelatihan (follow-up). Komitmen mengajar guru setelah Pelatihan Kepemimpinan Kenabian (pascates) dan satu bulan setelah pelatihan (follow-up) diketahui nilai Sig 0,426 (nilai Sig > 0,05 ) yang berarti hipotesis ditolak yaitu tidak ada perbedaan komitmen mengajar guru yang signifikan setelah pelatihan (pascates) dengan satu bulan setelah pelatihan (follow-up). Hal tersebut dapat dilihat dengan grafik berikut: 


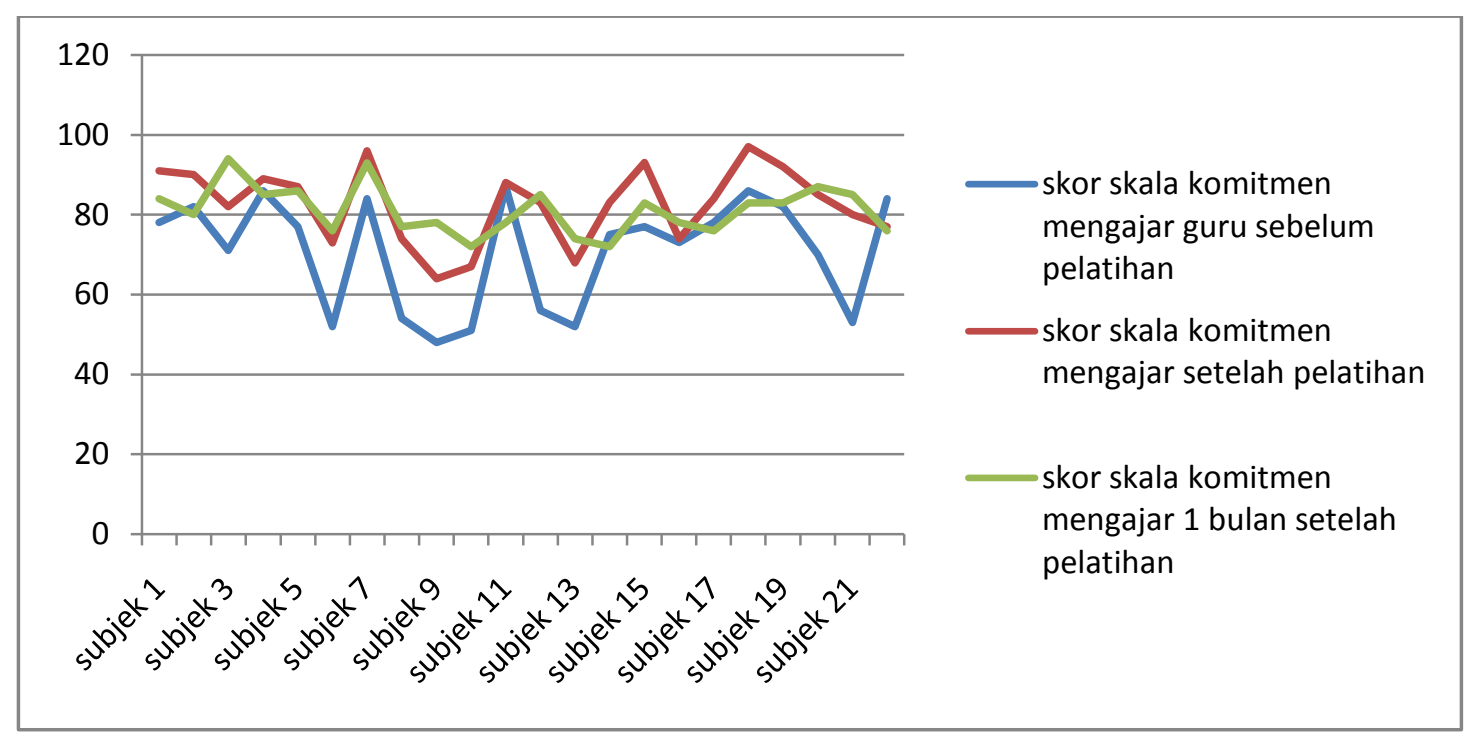

Grafik 1. Perbandingan Skor Skala Komitmen Mengajar Guru Pretest-PosttestFollow Up

\section{PEMBAHASAN}

Problematika seperti kurang tingginya komitmen mengajar guru bisa terjadi dalam sebuah lembaga pendidikan, seperti yang terjadi pada SDIT " $\mathrm{H}$ " di mana para gurunya terdiri dari berbagai macam karakter dan latar belakang baik ekonomi, pendidikan, suku, aliran agama dan lain-lain. Rendahnya komitmen mengajar guru dapat disebabkan beberapa hal antara lain karena kurang optimalnya guru dalam mengajar, kurang tegasnya guru, kecenderungan kurangnya disiplin terha-dap pekerjaan, beberarapa guru datang terlambat ke sekolah dan terlambat memulai pelajaran, kurang memiliki tanggung jawab terhadap tugas, dan kurangnya keinginan guru dalam meningkatkan keterampilan mengajarnya.
Apabila sekolah atau organisasi ingin maju, maka dibutuhkan komitmen terutama dari orang-orang yang memiliki peran penting di sekolah seperti guru. Guru-guru perlu memiliki komitmen yang tinggi terutama dalam mengajar agar dapat melaksanakan pengajaran dengan baik. Komitmen mengajar guru yang tinggi dapat meningkatkan kualitas guru dalam mengajar, dengan kualitas guru yang baik maka dapat memberikan kontribusi bagi sekolah demi keberhasilan pendidikan (Erawan, 2010).

Penelitian ini bertujuan untuk memberikan intervensi berupa Pelatihan Kepemimpinan Kenabian kepada guruguru di SDIT "H" sebagai upaya untuk menguji apakah Pelatihan Kepemimpinan Kenabian dapat meningkatkan komitmen mengajar guru di SDIT "H". Pelatihan Kepemimpinan Kenabian dalam peneli- 
tian ini merupakan pelatihan yang disajikan dengan konsep kepemimpinan berdasarkan cara Nabi Muhammad SAW memimpin umatnya, yakni belajar dari keteladanan sifat-sifat Nabi Muhammad SAW yang disajikan dalam sesi-sesi seperti sidiq, amanah, tabligh, fahonah.

Pelatihan Kepemimpinan Kenabian dirancang berdasarkan teori experiential learning yang menyatakan bahwa pelatihan mampu mengubah struktur kognitif, sikap serta keterampilan yang dimiliki oleh peserta. Experiential learning ada lima tahapan, yaitu experiencing, publishing, processing, generalizing dan applying (Aryani \& Supriyanto, 2003). Guru SDIT H yang mengikuti seluruh sesi pelatihan berjumlah 22 orang, sedangkan beberapa guru lainnnya yang tidak mengikuti sesi pelatihan secara lengkap diperbolehkan untuk tetap mengikuti beberapa sesi selanjutnya namun data tidak disertakan dalam analisis penelitian.

Pada saat Pelatihan Kepemimpinan Kenabian berlangsung, beberapa guru baru merasakan tahapan experiencing, publishing, processing, generalizing, sehingga waktu proses pemberian skala pascates ada beberapa guru belum terlihat perubahan yang menonjol dalam komitmen mengajarnya, sedangkan setelah satu bulan pelatihan berjalan seluruh guru sudah masuk pada tahapan applying, yang mana mereka menerapkan komitmen yang telah mereka sepakati pada saat pelatihan.

Berdasarkan hasil pengukuran satu bulan setelah pelatihan diketahui ada peningkatan skor skala komitmen mengajar guru di SDIT " $\mathrm{H}$ ", sehingga diketahui bahwa Pelatihan Kepemimpinan Kenabian memiliki pengaruh untuk meningkatkan komitmen mengajar guru di SDIT " $\mathrm{H}$ ".

Berdasarkan proses Pelatihan Kepemimpinan Kenabian yang telah dilakukan dalam penelitian ini memberikan pengaruh pada peningkatan komitmen mengajar guru SDIT " $\mathrm{H}$ ". Hal ini terlihat saat setelah pelatihan, guruguru lebih bersemangat hadir ke sekolah, hadir dan memulai pelajaran dengan tepat waktu, lebih terlihat tegas dan disiplin dengan aturan yang ada di sekolah dan kini guru lebih terlihat lebih bertanggung jawab terhadap kewajiban utamanya mengajar.

Hasil penelitian menunjukkan data prates dan pascates skala komitmen mengajar guru diketahui Sig 0,000 (nilai Sig $<0,05)$ berarti hipotesis diterima yaitu ada perbedaan komitmen mengajar guru yang signifikan sebelum pelatihan (prates) dan setelah Pelatihan Kepemimpinan Kenabian (pascates). Komitmen mengajar guru dilihat lagi hasilnya satu bulan setelah pelatihan (follow-up) diketahui nilai Sig 0,006 (nilai Sig < 0,05 ) yang berarti hipotesis diterima yaitu ada perbedaan komitmen mengajar guru yang signifikan sebelum pelatihan (prates) dan satu bulan setelah pelatihan (followup). Komitmen mengajar guru setelah Pelatihan Kepemimpinan Kenabi-an (pascates) dan satu bulan setelah pelatihan (follow-up) diketahui nilai Sig 
0,426 (nilai Sig > 0,05) yang berarti hipotesis ditolak yaitu tidak ada perbedaan komitmen mengajar guru yang signifikan setelah pelatihan (pascates) dengan satu bulan setelah pelatihan (follow up). Berdasarkan data tersebut dapat disimpulkan bahwa Pelatihan Kepemimpinan Kenabian dapat meningkatkan komitmen mengajar guru.

Setelah dilakukan evaluasi pada penelitian, maka didapatkan beberapa keterbatasan penelitian, antara lain: 1). Desain eksperimen tidak terdapat kelompok kontrol, peneliti menggunakan desain The One Group Pretest-pascates, 2). Alat ukur skala komitmen mengajar guru yang dipakai memiliki aitem yang sedikit dengan nilai reliabilitas 0,884 sehingga diharapkan pada penelitian selanjutnya peneliti lebih mampu memodifikasi skala dengan reliabilitas yang lebih tinggi, 3). Kurangnya koordinasi antara kepala sekolah dengan guru yang lain mengenai wajibnya mengikuti kegiatan dalam pelatihan tersebut.

\section{SIMPULAN DAN SARAN}

\section{Simpulan}

Simpulan dalam penelitian ini adalah Pelatihan Kepemimpinan Kenabian dapat meningkatkan komitmen mengajar guru di SDIT " $\mathrm{H}$ ", hal tersebut dapat ditinjau dari adanya peningkatan pada beberapa hal seperti guru kini lebih memiliki keinginan untuk bertanggung jawab dalam proses belajar-mengajar di sekolah, lebih disiplin, dan memiliki keinginan untuk lebih terampil dalam mengajar yang tinggi.

\section{Saran}

Saran dalam penelitian ini antara lain hendaknya para guru dapat dapat konsisten dalam menjalankan komitmen yang sudah dibuat saat pelatihan. Melihat tanggapan positif dari guru terhadap program Pelatihan Kepemimpinan Kenabian, maka sekolah dapat menerapkan program serupa misalnya dengan ceramah/siraman islami setiap minggunya. Sekolah juga hendaknya meninjau kembali serta melaksanakan standar operating procedure maupun deskripsi pekerjaan guru. Bagi Psikolog, hendaknya hasil penelitian ini selanjutnya dapat dijadikan dasar ilmiah untuk kajian program Pelatihan Kepemimpinan Kenabian sebagai suatu usaha preventif dan kuratif dalam usaha meningkatkan komitmen mengajar guru, Program Pelatihan Kepemimpinan Kenabian ini dapat ditetapkan sebagai penanganan pada lembaga pendidikan atau organisasi yang kurang memiliki komitmen pada anggotanya. Bagi peneliti selanjutnya perlu mengupayakan agar semua guru dalam satu sekolah mengikuti pelatihan agar hasil pelatihan dapat lebih optimal.

\section{DAFTAR PUSTAKA}

Adz-Dzakiey. M.H.B. (2009). Kepemimpinan Kenabian. Yogyakarta: Islamika. 
Andansari, N. (2010). Pelatihan Kepemimpinan Kenabian untuk Meningkatkan Kemampuan Pemecahan Masalah pada Karyawan BMT X. Tesis (Tidak diterbitkan). Magister Profesi Psikologi. Yogya-karta: Universitas Islam Indonesia.

Alawiyah, E. M. L. (2012). Laporan Kasus Sistem Praktik Kerja Profesi Psikolog Magister Profesi Psikologi. Laporan Peneltian (Tidak diterbitkan). Yogyakarta: Universitas Islam Indonesia.

Ariyani, D. \& Supriyanto, S. (2003). Peningkatan Efektivitas Tim Kerja Asuhan Keperawatan Melalui Metode Arung Alam. Jurnal Administrasi, Kebijakan, Kesehatan. 1 (3), 140145. Surabaya: Universitas Airlangga

Bahry, S. (2012). Manajemen Kelas ditinjau dari Kepribadian dan Komitmen Kerja Guru di Sekolah Menengah Atas. Tesis (Tidak diterbitkan). Yogyakarta: Fakultas Psikologi Universitas Gadjah Mada.

Bowling, A. (2002). Research Methods in Health: Investigating Health and Health Services 2nd Edition. Buckingham Philadelphia: Open University Press.

Budiharto, S. \& Himam, F. (2006). Konstruk Teoritis dan Pengukuran
Kepemimpinan Profetik. Jurnal Psikologi (Fakultas Psikologi Universitas Gadjah Mada). 33 (2), 121-132.

Ching, S.L \& Kee, D.M.H. (2012). Work Values-Career Commitment Relationship of Generation $Y$ Teachers in Malaysia. International Conference on Economics Marketing and Management. IPEDR. 28 (3), 242-246.

Colladarci, T. (2010). Teachers' Sense of Efficacy and Commitment to Teaching. Journal of Experimental Education, 60 (4), 323-337.

Crosswell, L. \& Elliott, B. (2012). Committed Teachers, Passionate Teachers: The Dimension of Passion Associated with Teacher Commitment and Engagement. Paper presented at the International Symposium on Teacher Commitment at the European Conference on Eduactional Research, Lille, France.

Erawan, P. (2010). A Comparison of Teaching Efficacy, Commitment to Teaching Profession and Satisfaction with Program Effectiveness of Teacher Students Under the 5 Year-Program Curriculum and Those Under the $4+1$ Year-Program Curriculum. European Journal of Social Sciences, 14 (2), 250-261. 
Johnson, D, W \& Johnson, F, P. (2001). Joining Together Group Theory and Group Skills. Boston: Allyn \& Bacon.

Mkumbo, K.A.K. (2012). Teachers' Commitment to, and Experiences of, the Teaching Profession in Tanzania: Findings of Focus Group Research. International Educational Studies, 5 (3), 222-227.
Park, S., Henkin,A.B., \& Egley, R. (2005). Teacher Team Commitment, teamwork and Trust: Exploring Associations. Journal of Educational Administration, 43 (4/5), 462- 479.

Widhiarso, W. (2009). Meninjau Skala Kepatutan Sosial Melalui Teori Respons Butir. Laporan Penelitian (Tidak diterbitkan). Yogyakarta: Fakultas Psikologi Universitas Gadjah Mada. 